\title{
Homer in the laboratory: a Feyerabendian experiment in sociology of science
}

Mark Erickson

\section{Author's bionote}

Mark Erickson is Reader in Sociology at the University of Brighton, UK.

Dr Mark Erickson

School of Applied Social Science

University of Brighton

Falmer

Brighton BN1 9PH

Tel: 01273641085

Email:m.erickson@brighton.ac.uk

Note: this paper includes a small amount of Ancient Greek text. This may present some problems in terms of onscreen display. Ancient Greek characters have been inserted as Unicode characters and should be visible in a word processor when a Greek character keyboard is selected. 


\begin{abstract}
For philosopher of science Paul Feyerabend, an outcome of the Platoled victory of philosophers over poets is the 'conquest of abundance' where abstraction replaces the 'richness of being'. This poignant motif is visible in the project of the social sciences, where theory describes classificatory schemas that can be imposed upon the social world to categorise and, subsequently, explain it. However, Homer's writings (which predate Plato) provide a completely different frame of reference. By reimagining ourselves within this work we may be able to rethink and reconfigure our understanding of science, and perhaps even the practice of science. This paper reports on a Feyerabendian 'experiment' in sociology of science which attempts to write contemporary scientific production from the frame of reference of Homer. This new methodology leads to fragments of epic poetry which act as a provocation to, and a disruption of, sociology of science and STS and their ways of making sense of science in society.
\end{abstract}

\title{
Keywords
}

Sociology, Homer, Feyerabend, STS 


\section{Introduction}

Understanding science - what it is, how it is done, why it is done - is an important task for, amongst others, social scientists; their efforts in this regard can have significant benefits for society. The importance of scientific activity and knowledge is widely recognised, and the importance of public understanding of science is widely declared as a significant aim. Science is all around us, permeates our lives, thought and cultures, has economic benefits, and costs, for us all. But despite this we have an ambivalent and complicated relationship to science. Science is highly valued in our society, and the production of scientific knowledge in itself is considered to be a good thing. But there is also considerable suspicion as to the purposes to which science is put, particularly when it encroaches on our lifestyles and moral values. This is, in part, a consequence of the stereotypical story that we often tell ourselves about science: that it is external and neutral, an institution populated by selfless and dispassionate individuals working for a common good. We are disappointed when we find out that our stereotypes are inaccurate and that science is actually a part of society and is being made by individuals who have mundane concerns and connections to the rest of us, but also disappointed when we are correct and science acts in aloof and remote ways (Erickson 2015; Fuller 2010). On top of this is the sheer amount of science: the growth in the quantity of scientific knowledge, in the forms of what we are now forced to call 'outputs' (at least in UK HE) is striking, but it feels as if we are not getting anywhere despite this. Put simply, the more we know about science and the more science we have, the less we feel we understand it. 
Why is this? Why do we find it difficult to make sense of science? It is not sufficient to simply say that science is complicated and this makes it difficult to understand. To be sure, some aspects of formal science require participants to have considerable specialist knowledge and skill, and these are not available to many people in society. But this does not address the fundamental problem which is not one of content (e.g. understanding quantum mechanics or molecular microbiology) but of form (what formal science as an endeavour, an institution and a form of knowledge actually is). We can see this problem of form quite clearly when we observe interactions between researchers from different disciplinary backgrounds: even formal scientists, say physicists and molecular microbiologists, will not necessarily agree on what 'science' is, but when we bring social and natural scientists together the result is, more often than not, misunderstanding, miscommunication and mistrust. In this paper I will attempt to address some of the fundamental roots of this problem, and propose a novel methodology, using the philosophy of Paul Feyerabend as a starting point, which may free up our thinking about science.

For Feyerabend the roots of our strange and difficult relationship to science, even for those inside science, lie in the language, forms of thought and theories that we have inherited and that we use to try and make sense of the world around us. Feyerabend's later work, from Against Method until his death, contains a number of consistent themes on the history, philosophy and practice of formal science (Feyerabend 1978, 1987, 1999, 2011), and many commentators provide helpful summaries of this (e.g. Couvalis 1989; Preston 1997). The posthumous discovery of the MS of Feyerabend's Philosophy of 
Nature (Feyerabend [2009] 2016) shows that these themes were extant in his 1960s and early 1970s works too. Although Feyerabend's work has attracted a great deal of attention in recent decades, there has been hardly any analysis or discussion of his preoccupation with archaic and ancient Greek thought (Heit 2016), yet all of his later work is underpinned by an observation that he restates again and again. It is that the people of the archaic world, the people who lived before the Presocratics, the people who Homer originally wrote about and for and who lived before, roughly, 700 BCE, thought about and experienced the world differently from later people. This insight is, for Feyerabend, crucial in understanding why we think about, practice and value science in the way that we do today.

Feyerabend's philosophy of science, most clearly articulated in Against Method (1978), is not anti-science, but it is anti-dogma. He debunks the idea that there is standard scientific method that is deployed in laboratories; instead he sees a loose affiliation of pragmatic methods, social practices, guesswork, hunches and even fabrications that lead to the production of scientific knowledge. This begs the question of why we tell ourselves the standard story of science and scientific method as a rational, fixed, superior way of understanding the (natural) world? For Feyerabend the reason lies in the 'grammar' of our thought: we hold a comprehensive view of the world that influences our thought, our behaviour and our perceptions $(1978,223)$. Most importantly we have an internalised classificatory scheme, one that is largely covert, which creates patterned resistances to alternatives: we simply cannot think of other ways of making sense of the world or classifying objects in the world because we are locked inside a worldview that circumscribes our 
conceptual horizons. There are many features of this and many implications. The most important one for us as observers and practitioners of formal science is this: our worldview tells us that our theories of the world are better than our experiences of the world. In our world we have theories that help us explain things to us, and concepts that classify things (people, events, objects) into discrete categories. This is, of course, fantastically useful: without these devices we would be swamped with phenomena and unable to form any lines of action. But there are negative sides to this: we simply cannot see other possibilities. Feyerabend calls this situation 'conceptual totalitarianism' $(1978,262)$; other philosophers have identified something similar.

How long has this been the case? Not for ever, but for much longer than a standard history of ideas might suggest. The story that we often tell ourselves in Western academia is that the crucial change in how we understand came about at the time of the Scientific Revolution in the eighteenth century (e.g. Wallerstein 2004, 2006; Foucault 1970; Shapin and Schaffer 1985). Feyerabend disputes this; for him the structure of our worldview, our privileging of theory over experience, dates back to ancient Greek society and, specifically, to the theories of Plato (although Feyerabend traces the roots of this in the writings of the Presocratics, as does Karl Popper $(1945,1998))$.

For Popper, the start of rational, critical and scientific thought can be identified quite clearly in the work of Parmenides. 'Parmenides' theory may be described as the first hypothetic-deductive theory of the world' $(1998,17)$ and this marks the start of a tradition which places theory at the heart of rational 
investigation, privileging theory above observation and experience. The rationalist tradition is 'the only practicable way of expanding our knowledge' $(1998,23)$, and it does this through conjecture: proposing theories which are better than experience or observation as they are a) able to explain more and b) can be better tested. $(1998,24)$. From this we can see a marked rupture between Presocratic thought and its predecessors. For Popper, this rupture is visible in other ways; for example, Homer has a quite different view of history from later writers. "What Homer tries to stress and explain is not the unity of history, but rather its lack of unity." (Popper 1945, 11) In marked contrast, the Presocratic Heraclitus emphasised the unity of history and provides a strong historicist account.

Looking into the worldview of those who lived before the Presocratics is not easy; by inference we can reconstruct what Parmenides was arguing against, through inverting his thought. But this kind of inference drawn from negation is neither particularly secure, nor rich. What was the world before Parmenides like? For Feyerabend it was a world that was understood very differently, and he finds evidence for this in the epic poems of Homer.

The work of Homer, specifically the Iliad and Odyssey, were composed at the same time as geometric art was being made, the period of ancient Greek history called the archaic. The lliad, Homer's epic 15,693 line poem about the Trojan War, in particular, shows people thinking very differently about their world and themselves. The lliad and the Odyssey were used through much of the $20^{\text {th }}$ century as evidence of the existence of a people (archaic ancient Greeks) who had primitive conceptions of the self, morals and ethics and the world. This 'progressivist' account of Homer's audience 
was expounded most forcefully Bruno Snell (1953) and extended by, notably, Adkins $(1970,1972)$, and largely debunked, equally forcefully, by Bernard Williams in his seminal Shame and Necessity (1993). Whilst Feyerabend does concur with the progressivists in terms of the evidence that they deploy - for example he, too, argues that the archaic Greeks did not have a sense of being complete and undivided individuals - Feyerabend is no progressivist for he does not argue that this mode of being (what he calls 'cosmology A' where knowledge of an object is achieved through the enumeration of its parts but complete knowledge is never possible) is in any way deficient to what came later. Far from it; for Feyerabend (and also for Richard Rorty $(1980,44-5)$ ) our departure from the worldview of the pre-Presocratics marks a catastrophe in terms of the organization of thought, a position quite at odds with either the progressivists or, for that matter, Popper. It marks the beginnings of our reliance on theory above experience, and of deploying totalising conceptual and classificatory schemes that serve to 'conquer abundance' (Feyerabend 1999): Feyerabend calls this way of understanding the world 'cosmology B' where true complete knowledge can be achieved (1978, 260-1). There is good reason, therefore, for us to reconsider how thought worked in the prePresocratic period as a way, and I would argue the only way available to us, of constructing an alternative account of science that allows us to disrupt our current thinking. There are very few texts from this period that we can go to for inspiration and a place where we can infer how to think in a different way, and only one major source'; the poems of Homer. 


\section{Homer}

We know almost nothing about Homer; who he or she was, if Homer was an individual or a group of people, when they lived, where they lived, and so on. Homer's life and existence has been subject to a great deal of conjecture and myth-making. All that we can know comes from the two surviving texts that are credited to 'Homer', the Iliad and the Odyssey (and even here there is a very long tradition of argument and debate between those who think the poems have the same author, and those who don't; Samuel Butler's The Authoress of the Odyssey (1897) is a classic example). These epic poems which were written down in about 700 BCE have been subject to critical analysis for more than two and a half millennia, and in that period of time a massive body of scholarship has been generated. That such a huge amount of writing has been generated, such immense efforts made across the centuries to try and understand Homer better, is clear evidence that there is something remarkable about Homer's works. Even today both the Iliad and the Odyssey command attention, respect and imitation. New translations of Homer appear regularly, and classic translations are still being published. Recent bestsellers from Mary Beard (2013) and Adam Nicolson (2014) both make a strong case for the continuing relevance of Homer's works. Homer's poems have been turned into comic books and graphic novels, children's books and movies: Wolfgang Petersen's 2004 film Troy, starring Brad Pitt as Achilles, Eric Bana as Hector and Orlando Bloom as Paris, was the $8^{\text {th }}$ highest grossing film of that year and is currently in the top 150 highest grossing films of all time, and the Coen Brothers' 2000 adventure comedy O Brother, Where Art Though is loosely based on Homer's Odyssey. In 2015 alone the BBC staged a complete rendition of the Iliad, Simon 
Armitage's reinterpretation of Homer, The Odyssey: missing presumed dead, went into production, and the National Theatre of Wales' production of Christopher Logue's interpretation of the Iliad received five star reviews. Madeleine Miller's novel The Song of Achilles retells the story of the Trojan War from Patroclus' viewpoint (Miller 2011) won the Orange Prize for Fiction in 2012. Needless to say, our contemporary interpretations and representations of Homer tell us much more about ourselves than they do about Homer's society and culture, but that should not detract from the fact that Homer is still an active presence in contemporary society and culture. The characters and plot from Homer's epic poems are embedded in our society and culture and have been for a very long time, so embedded that we sometimes fail to notice their presence. Think of mentoring: a very common practice, but the original mentor was Mentor in the Odyssey, a friend of Odysseus and the advisor to his son Telemachusii.

The Iliad is clearly of the past: it recounts the story of one incident and its consequences in the Trojan War, events that took place about three millennia ago. It is the first extant account of what the poet thought was historical 'fact'; for the poet the characters and events, the gods and goddesses, of the Iliad are quite real and we can assume that the original audience would have had the same view. But the Iliad is also of the present in that the poem speaks to us in a very meaningful way; it is hard to read the poem without finding a connection to one's own life and, at the very least, the poem reminds us of the entrenched position of the tales of the Trojan War in our contemporary culture. This is a text that we can have 'faith' in; not religious faith (although that could be possible if one were so inclined) but a 
sense that the text is worthy of our attention and can tell us something important.

Homer's style is remarkable and distinctive, a result of the method of composition and the conventions of the day. Homer was illiterate, the Iliad is an oral composition and to aid the bard reciting such a lengthy poem from memory Homer uses repeated epithets, verses and similes; Achilles is 'swiftfooted' even when he is sitting down and eating, for example. But as well as these stylistic characteristics there is a feature of Homer's style that marks a sharp contrast to later modes of poetical composition; Homer's sentence construction is 'a paratactic rather than a syntactic mode of expression, in which thoughts, or the elements of sentences, are set out side by side, as it were, rather than being built into a kind of pyramid.' (Kirk 1985, 31)

Homer's world is a world of myth, not theory, but it is a coherent and sensible worldview. Nature is understood as the expression of supernatural beings - gods, goddesses, nymphs and so on - not as conceptualised and categorised substance. Whilst this seems irrational to us, it is quite 'rational' to the people of Homer's time (Feyerabend 2016, 78). Gods and goddesses, expressed in myth, are quite 'real' at this time.

Between these things we can piece together an understanding of a society where people thought about and perceived the world in ways very different to us. Feyerabend sums this up: '[T]he archaic world is much less compact than the world that surrounds us, and it is also experienced as being less compact.' $(1978,244)$. For Feyerabend our difficulties in understanding science are a consequence of being part of cosmology B and its conceptual totalitarianism. Our world has been compacted, and it is in this form that we 
encounter it and then experience it, aided and abetted by our concepts and theories of the world.

But perhaps there is something we can do to disrupt this way of experiencing and understanding the world; perhaps we can retrieve something from cosmology A, something that we could have some element of faith in that will put into relief our cosmology B understanding of, in this case, science? We revere (and revise) Homer, we know the story of the Trojan War, have heard of Hector and Achilles, Odysseus and Priam, Zeus and Hera, Paris and Helen. But what if instead of writing about the army ranged across the plains and beaches outside the gates of the city of Troy, Homer had written about scientists engaged in their work? What would we see from a cosmology A perspective on formal science and knowledge production? What would the poet see if they found themself in a laboratory?

\section{Homer in the laboratory}

Can we use the differentness of Homer's way of thinking, seeing, experiencing and expressing to help us understand science in contemporary society? Two distinct ways suggest themselves. One way is to use the Iliad as a metaphor for contemporary science, as a lens through which we can 'read' formal science; a process of comparison. What do we learn, if anything, by comparing the practices of the heroes of the Iliad with those of contemporary formal science; what comparisons can we draw between the social structures of the Iliad and those of contemporary science? One, perhaps rather obvious, parallel is the social structural arrangement of archaic ancient Greek communities and the social structural arrangement of the laboratory or similar 
site of the production of scientific knowledge. The fundamental unit of social organization in Homer's world is the oíkoo (oikos; household) which has a single leader and a large number of support staff arranged hierarchically (Finley 1964). The leader is responsible for the security of the household. Outside the oíkoo the world is harsh and insecure; inside there is stability and security. The head of the oíkoo must constantly accumulate wealth in the form of possessions: this is not greed but necessity. Each head of an oíkoo is in competition with other heads of oíkoo for wealth, prestige, prizes. The leaders of oíkoo can and do come together to discuss matters and can even take part in joint enterprises such as heading off to attack a city like Troy.

Translate this into contemporary conditions of how labs operate. There is a single leader (usually) who is responsible for the security of the team. There is a large number of support staff and these are arranged hierarchically. Outside this esoteric scientific community (Fleck 1979; Erickson 2015) the world is harsh and hostile - it is a difficult labour market even for highly experienced and qualified postdocs - but inside there is stability and security, at least until the end of a grant. The head of the team must constantly apply for renewed funds; this is not greed but necessity for without these funds the team would fold. But accessing funds is through a competitive process, and each lab is in competition with other labs, other than when they get together to form alliances of varying degrees of permanence. Competition is the order of the day, but alliances and joint enterprises can be formed such as when applying for large research grants.

A second obvious parallel concerns the motivations of the heroes of the Iliad and the motivations of formal scientists involved in the production of 
scientific knowledge. The characters in the Iliad are motivated almost entirely by their need to acquire honour (Adkins 1972, 15; Williams 1993). They get honour through deployment of skill, being good and achieving success. Being

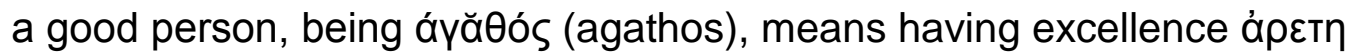
(arete). This is an all or nothing situation. Having good intentions counts for nothing if one's action results in failure. The characters who are effective and successful (in the context of the Iliad this is measured in terms of fighting) are áyă $\theta$ ó and $\dot{\sigma} \sigma \theta \lambda$ ○ (esthlos). But when failure occurs it is shameful and base:

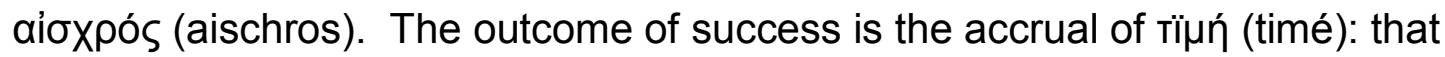
which is paid in token or worth.

'Honour is enhanced by the possession and exercise of personal qualities that are exceptionally esteemed for their usefulness to their possessor and to the community: chief of these are courage and strength and military and athletic skills, but also resourcefulness and persuasive speech, and, to a lesser extent, physical beauty.' (Camps $1980,7)$

Are these factors at play in contemporary science? Honour and status accrue to good experimenters who are successful in achieving results, publications and funding outcomes. Shame accrues to failed experiments, and there is a certain sense that good intentions are of little import here. I am not trying to say that formal scientists are all ruthless and unsupportive of their colleagues; far from it. However, it is the case that science is agonistic, it proceeds through contestation and argumentation whereby only one person or perspective is the winner (Popper 2002). It produces a rigid hierarchy that recognises skill and success and punishes failure and lack of success 
(Erickson 2015). This is all the more the case in contemporary academic science where 'publish or perish' is the order of the day.

We could go on (and on): it is, just from these two examples, clear that we can read science through a Homeric lens. But this is, in many ways, too easy. We could, after all, have chosen any classic text as a lens through which to view science - Don Quixote or Gilgamesh for example. Certainly, there is something about the Iliad as the first extant written account of 'fact' that marks it out for special treatment, but simply being able to draw parallels is not, in my opinion, sufficient to help us move into a cosmology A frame of reference such that we can disrupt and confront our cosmology B mode of thinking about science. Indeed, it may even be that we are doing quite the opposite. Reading the laboratory through the lens of the Iliad is more a process of imposing our current concepts and categories backwards; shoehorning Homer into our world. This becomes obvious when we think about two themes that this form of reading will not allow to enter: there is no room for the Homeric gods in such a reading, and the relentless and bloody violence of the Iliad, itself perhaps the most striking feature of the poem, is not something we will find in contemporary formal science. By reading the Iliad as a metaphor for the production of scientific knowledge we are deliberately ignoring what the Iliad is actually about: fate and the awfulness and futility of war.

But rather than reading through Homer, using the Iliad as a metaphor for contemporary science practice, perhaps we could try something a bit more ambitious. Perhaps we could try and imagine what Homer would write about 
contemporary science practice. If this were possible then we would begin to start addressing Feyerabend's observation that the cosmology B mode of thought, instigated by Parmenides and consolidated by Plato (Feyerabend 2016, 147ff), is too dominating and cannot be escaped from. If Homer were here now what would Homer say? And would Homer be exhibiting a mode of thinking, understanding and perceiving that came from a time and space that was not overrun with the cosmology B worldview? This is where my Feyerabendian experiment in sociology of science really starts. Would it be possible by immersing oneself in the laboratory and in the Iliad, its language and form, its stories and characters, to produce fragments of epic poetry that, using a cosmology A perspective, disrupt and unsettle our understanding of formal science? Can we produce a Homeric account of a microbiology laboratory, its participants, practices and environment?

\section{Method}

This experiment took place in 2015 in a university laboratory that specialised in applied microbiology with a particular focus on environmental health, water quality and waste water treatment. The action of the Iliad takes place over 54 daysiii; accordingly I allocated myself 54 working days to try and complete the project. My research method was very simple: I observed and participated in all the activities of the laboratory and made notes on these in field work diaries. At the same time I read and re-read the Iliad (one book per day where possible) and made detailed notes on the text. To supplement this I also read as much Homeric scholarship as I could, and again made copious notes. All the members of the laboratory were informed about the project and 
signed consent forms indicating that they were willing for me to observe them in their workplace and use the material I collected. To preserve anonymity I have assigned all the laboratory personnel names from the Iliad, names that I felt were in keeping with at least some aspects of their character and/or biography. On day 1 I was given a comprehensive induction to the laboratory and its processes by the lead technician in charge of Health and Safety, given a locker, a lab coat and a swipe card that provided access to the lab.

The laboratory was very similar to other microbiology labs I have carried out research in: it had standard microbiological equipment (incubators, fridges, Bunsen burners, vacuum taps, clean air cupboards, reagents, sinks, etc.), and did experiments that many other laboratories carry out. One end of the laboratory was partitioned off: this was the 'dirty' end where raw sewage and other contaminated samples were processed. The other end was designated the 'clean' end: here the molecular microbiology work, using qPCR, was carried out. The workspace at peak times had up to ten people in it. The personnel in the lab fell into three categories: PhD students, Postdoctoral Researchers, Technicians. Occasionally one of the senior academics, who were in charge of the lab and its projects, would visit. In general, the lab was a calm, but busy, space.

One difference to other microbiology laboratories I have worked in was the need to collect fresh samples, either from 'natural' sites such as water courses and rivers or from waste water treatment plants (colloquially called 'sewage farms'). These field trips took up a lot of time for members of the team, and were a regular occurrence. Other regular occurrences were informal group meetings which generally involved shared food or 
refreshments. The team in the lab spent a lot of time in one another's company both in the lab and outside it. The head of the lab arranged for a weekly informal meeting in the coffee bar to share news, gossip and information about how projects were proceeding. It was obvious from quite early on that the shared culture of the laboratory was important to the participants and how they perceived their work.

Gradually I felt myself being more and more absorbed into the day-today operations of the lab, and I also could feel my immersion in Homer having an effect upon me. My 'exploration' of Homeric scholarship (I think exploration is the best term; I am not nor could I hope to be a classics scholar, but I was mapping out and exploring the terrain in a lot of detail) was facilitated by advice from Dr Elizabeth Pender, Department of Classics at the University of Leeds, and also by deciding to focus on just using a parallel (ancient Greek English) text of the Iliad (Homer, Wyatt and Murray 1999) and trying to expand my ancient Greek vocabulary and comprehension.

And that is how the field work proceeded: I would go to the lab in the morning, meet the colleague who I would be shadowing for the day, watch what they were doing, sometimes doing some of the experimental work for them, or accompany them on a field trip to a waste water treatment plant, and I would read in the lab. On non-lab days I would sit in the library and work my way through all the Homeric scholarship texts I could find and considered relevant. Detailed readings of each book of the Iliad were facilitated by using the Cambridge University Press six volume commentary (Kirk 1985, 1990; Janko 1992; Edwards 1991; Richardson 1993; Hainsworth 1993). My new colleagues in the lab got used to me being there pretty quickly; whilst I did not 
have a name for my research method or role, they did, calling me the poet or artist in residence. I think that is a good description of what I was doing: effectively, I was waiting for the Muse to visit me so I could write epic poetry.

\section{Results}

On day 14 I managed to write a simile. This came about while working with Diomedes and watching him place his bacteria into the incubator. As he shut the door he said 'they need to eat and grow'. My simile:

And like the little children that after their lunch need their sweet repose, So the bacteria need to eat and grow.

Idomeneus, a postdoctoral researcher, later told me that he thinks of his bacteria as being 'his babies', so I felt that I had some corroboration for my simile. However, fourteen days into the project and I only had two lines; this did not feel like good progress.

By this time I have, however, worked out which character I am: Nestor of Gerenia. He's a lot older than everyone else in the Iliad, is full of boring and rambling stories about the 'old days', is a bit narcissistic, is hanging around when not really wanted, and is a source of advice for the others - even though this advice is frequently either blindingly obvious or wholly inaccurate (as with Nestor's two pieces of advice to Agamemnon in Iliad book 2). Younger lab members ask me for advice on what they are doing and as I have frequently told them I am a sociologist the only reason for this must be my age and position in the university system. With no other 'authority figure' around and/or available they make do with me. Interestingly, Nestor comes from Gerenia (Iliad 2, 336); no-one now knows where this was (Kirk 1985, 
151). In the laboratory, as a sociologist surrounded by microbiologists, I feel I too am from a place no-one knows.

My field trips become quite regular: Idomeneus and I keep going back to the experimental reed bed about 90 minutes drive away. I get used to the rhythm of preparing media, collecting samples, processing the samples and collecting data. I begin to understand exactly what the experiments are trying to achieve. My laboratory colleagues are, I think, beginning to get used to me reading out passages from the Iliad and asking them to comment. But I still have almost no verses written. I did manage one more verse, on day 34 which describes how Thetis collected river water samples from the water course next to the waste water treatment site. It was a beautiful setting, with may blossom all around.

Steel-footed ${ }^{1}$ Thetis $^{2}$ wades into the river water

Shaded by the blossoming may tree

While the black crows ${ }^{3}$ watch the biofilm

I annotated the verse, partly as an aide memoire.

1. Steel-footed because her waders include steel toe caps, and also because footwear was a theme for the day. Helen, who was also on the trip today, was admonished by Thersites, one of the plant workers, for not wearing appropriate safety footwear.

2. 'Thetis' for this person as this is the only female character connected to water in the Iliad I can think of at the time. (I later changed her name to Elephene, who is human and not divine.) 
3. The crows were all around the trickle filter / biofilm mechanism, sometimes even riding on the rotating arms. They are looking for food.

The themes for day 36 came from the section of the Iliad I read on the way to the lab. That morning I was reading Odysseus' address to the assembled army in Iliad book 2 (2.278 ff), and focused on the simile of the serpent and the bird. I decided that I would 'look' for aspects of Odysseus

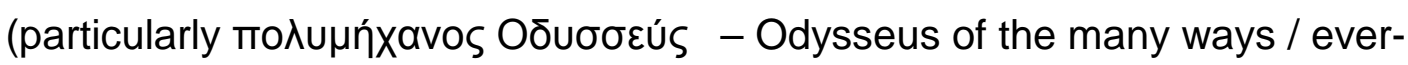
ready Odysseus / resourceful Odysseus), and 'look' for birds. On this day, after another sampling trip to the site I called 'Petroagros' to join with our colleagues from the University of 'Euboea', I sat down again in the lab in my Personal Protective Equipment (PPE), my 'armour', to watch Idomeneus carry out the first part of the experiment. I put the Iliad on the lab bench and opened my notebook, as I always did, and I thought to myself 'What on earth am I going to write now?' I honestly had no idea: there seemed little point in writing down the steps in the membrane filtration procedure yet again; l'd done this quite a few times already and I felt that it was unlikely I would record anything new.

But then I started writing, almost unconsciously; words started tumbling out. I wrote seven sets of verses that became Membrane Filtration in the Silver Tower that afternoon whilst sitting next to Idomeneus as he repeated the membrane filtration procedure. The final version below is an amalgamation and revision of those seven 'at bench' verses. Here it is:

\section{Membrane Filtration in the Silver Tower}


Down from the peaks of Olympus flashing-eyed Athene darted

And quickly came to the silver tower of the Achaeans.

Then she found Cretan Idomeneus of the many ways and spoke to him winged words:

'Will you now listen to me, knowledge-minded Idomeneus, son of Ioannis?

Then act now, and swiftly, according to the protocol.'

And Idomeneus armed himself in gleaming silver.

He put about his chest the labcoat of his leader, white as snow on the mountain peaks,

With secure fastenings, and fitted it to himself.

And about his hands he cast the purple gloves of nitrile,

And then his goggles, clear and sturdy,

And he took the valiant sharp-beaked pipette that fitted his grasp.

Resourceful Idomeneus assembled the filter units, clear and bronze-coloured and six in all,

Lit the fire of Hephaestus, and arrayed before him on the straight white bench

The lovingly prepared agar plates.

With flame-scorched forceps Athene-inspired Idomeneus of the many ways pulls the membrane filter from its sheath,

And as the mother sparrow gently places her chicks back in their nest and steps back to view her skill

So dextrous Idomeneus places the membrane filter into the unit 
Forgetting not his QSR libation to make.

The sharp-beaked pipette pierces the meniscus of the Falcon ${ }^{\mathrm{TM}}$, its due amount to take, and deliver,

As a heron dips into the marsh surrounded by the reed bed

And you, merciless and mighty vacuum, on taps' turn draw the liquid down

'Til dry as skin the sample is.

Then ever-ready Idomeneus with silver tweezers fresh-flamed

Pulls from the unit the membranes with their bacteria tamed

By vacuum’s strong pull, like Poseidon’s tides dragging the sailors to their doom The air pushed from their lungs while seabirds whirl

So Idomeneus, high in the silver tower stares through the window and pushes the air from under the membrane filters

Resting on their sustaining beds of wine-coloured agar.

And as a sparrow will return to her nest to feed her chicks so resourceful Idomeneus repeats his membrane filtration.

Just as the wild geese fly here and there, glorying in their strength of wing but always taking the same path to their nesting ground, so inventive Idomeneus carried out the procedure again and again.

And as the wily fox knows that the pheasant will return to the covert each night so Idomeneus returned to the start of the membrane filtration protocol.

Just as the herdsman knows the cattle will twice daily want milking so longenduring Idomeneus repeated the procedure twice more. 
And as the falcon swoops over the snake's lair but catches nothing, only to dive again at the same spot when it spies the serpent, so Idomeneus returned to the start of the sequence.

Just as the crafty crows fly down to the media then return to their roosts again and again through the long sunny day so much-enduring Idomeneus repeated the membrane filtration process nine times in all.

And like the little children who one day will explain the world to us through their different knowledge

But who after their lunch need their sweet repose, so the bacteria need to eat and grow.

Idomeneus, high in the silver tower, stacks the plates and places them in the warm embrace of the incubator,

And he hopes, as the seabirds whirl, and he waits patiently for the colonies of $E$. coli to emerge,

Ready for counting.

Membrane Filtration in the Silver Tower is one element in a cycle of verses I have called An Experimental Cycle. The full structure of the poem is:

Media Preparation

The Sampling Campaign

Membrane Filtration in the Silver Tower

The Catalogue of the Colonies

It is about 2,000 words long, roughly 220 lines (a long way short of the Iliad's 15,693 lines!). After reading the verses to my colleagues in the laboratory I 
carried on and wrote a second, shorter cycle: Patroklus (another postdoctoral researcher) specifically asked me to write about him and the 'shit factory' (his term, not mine). Patroklus at the Shit Factory is the first set of verses in the Patroklus cycle and is followed by Patroklus in the Silver Tower and Patroklus Fights the Fire. In total they amount to some 1100 words and about 135 lines. Writing the second cycle was easier because I knew what the method was, and also had had some encouragement from my lab colleagues that this was worth doing.

These verses, whilst Homeric in form, are not providing a full 'cosmology A' reading of the lab. Why not? Forget the author and their lack of poetic prowess for a moment. They cannot achieve this because they are embedded in a paradox. Simply stated the paradox is this: the laboratory, the formal scientist and formal scientific knowledge only exist because of the shift from cosmology $A$ to cosmology $B$, only exist because of the change in style of thought that came about at the time of the Presocratics.

Despite this problem it may be that the verses bring some sense of cosmology A to the scene and, as such, can serve some other purpose. Perhaps they can serve as a provocation coming from a shade from the past, an irritant that disrupts our usual way of thinking about formal science, laboratory work, scientists? To see this we need to interact with the verses, to subject them to a form of questioning that places us in a dialogue with them. This is a very similar process to how we can read the Iliad.

The Iliad can be approached in many ways: we can see this just from the range of interpretations that are abroad in popular culture. One way, 
however, is very old; questioning the text about its content and structure, asking it 'why' questions. This method dates back to Aristarchus of Samothrace (c. 220 - c. 143 BCE), was continued in medieval times and is a standard method used by Homerists today. The process of questioning the text, of considering one's interpretations of the text in the context of those of others, reaps great rewards in studying the Iliad. I am certainly not suggesting that the verses presented here deserve the same level of attention or that they will reap such rewards, but they can act as a tool to 'loosen' our thinking about science in a world dominated by scientism: engaging with the verses may help us to start to think differently about things. It seems vain to expect readers to do this for themselves, to actually sit with the verses, the wider descriptions of these and a copy of the Iliad. Rather than asking for that, and in the spirit of reflexivity and critical reflection I will provide an example of what this close interrogation and interaction with the verses reveals.

The following is a detailed reading of an excerpt from Patroklus in the Silver Tower and it is based on a very famous scene in the Iliad; Hektor confronting Patroklus and then killing him (Iliad 16.828 - 867). In my verses Patroklus and Automedon are carrying out an experiment which involves working with raw sewage and sludge; Hektor is the chief technician in charge of health and safety in the lab. The verse appears on the left hand side of the page, the commentary pertaining to the laboratory and formal science on the right, and the commentary and references to the Iliad appear underneath both of these.

Verse

Commentary 


\begin{tabular}{|c|c|}
\hline $\begin{array}{l}\text { The Achaeans brought forth the } \\
\text { sludge from the campaign }\end{array}$ & $\begin{array}{l}\text { The Achaeans are the microbiologists } \\
\text { working in this laboratory. Together } \\
\text { with other formal scientists they make } \\
\text { up 'the scientific community'. The } \\
\text { campaign is a sampling campaign, } \\
\text { but also a protracted struggle, against } \\
\text { a range of opposing forces, to } \\
\text { produce scientific knowledge. Like } \\
\text { the military campaign of Homer's } \\
\text { Achaeans, this campaign may suffer } \\
\text { setbacks and require revision, but it } \\
\text { will ultimately culminate in a victory of } \\
\text { sorts. The victory may not be worth } \\
\text { the effort. }\end{array}$ \\
\hline $\begin{array}{l}\text { But more than the foul waters had } \\
\text { they returned with, } \\
\text { For the fast flowing and eddying } \\
\text { currents foamed from the } \\
\text { vessels and soaked their steel- } \\
\text { toed boots } \\
\text { And a deep flowing river surrounded } \\
\text { them. }\end{array}$ & $\begin{array}{l}\text { Decanting the sludge and raw } \\
\text { sewage from } 50 \text { litre jerrycans into } 2 \\
\text { litre flasks was very, very messy and } \\
\text { a lot was spilled on the floor. } \\
\text { This was 'nature' being brought into } \\
\text { the artificial and constructed world of } \\
\text { the lab, and nature was making itself } \\
\text { felt very clearly. }\end{array}$ \\
\hline \multicolumn{2}{|c|}{ Iliad } \\
\hline
\end{tabular}




\begin{tabular}{|c|c|}
\hline & Nature is arbitrary. \\
\hline $\begin{array}{l}\text { As a man who guides its flow leads } \\
\text { from a dusky spring a stream of } \\
\text { water among his plants and } \\
\text { garden plots, a mattock in his } \\
\text { hand, and clears away the dams } \\
\text { from the channel, } \\
\text { And as it flows all the pebbles } \\
\text { beneath are swept along, and it } \\
\text { glides swiftly onwards with } \\
\text { murmuring sound down a } \\
\text { sloping place and outstrips } \\
\text { those who guide it, so Patroklus } \\
\text { and Automedon sluiced away } \\
\text { the foul water that surrounded } \\
\text { them. }\end{array}$ & $\begin{array}{l}\text { The laboratory is often seen as a site } \\
\text { of precision and control. There was } \\
\text { very little precision and control as the } \\
\text { raw sewage slopped all over our } \\
\text { boots, the floor, the vessels. } \\
\text { We cleared up the spillage using } \\
\text { buckets and mops (mundane tools to } \\
\text { us, as mattocks would have been to } \\
\text { Homer's audience) and sluiced the } \\
\text { raw sewage and sludge into the drain } \\
\text { in the floor. }\end{array}$ \\
\hline \multicolumn{2}{|c|}{ Italicised section is a quotation from Iliad 21.254-263 } \\
\hline $\begin{array}{l}\text { Yet though the flood had abated still } \\
\text { Hektor approached and rebuked } \\
\text { Patroklus for his foolishness and } \\
\text { he spoke winged words: } \\
\text { 'Patroklus, you said, I imagine, that } \\
\text { you would ignore our rules, that } \\
\text { you would achieve victory } \\
\text { without thought for health and }\end{array}$ & $\begin{array}{l}\text { Hektor is the head lab technician. The } \\
\text { lab technicians are Trojans, as } \\
\text { opposed to the experimenters who } \\
\text { are Greeks / Achaeans, because } \\
\text { there is a rivalry and opposition } \\
\text { between these two groups. Patroklus } \\
\text { feels that Hektor is trying to prevent } \\
\text { him achieving his project goals. }\end{array}$ \\
\hline
\end{tabular}




\begin{tabular}{|c|c|}
\hline safety.' & $\begin{array}{l}\text { Hektor, quite gently, tells Patroklus off } \\
\text { for pouring raw sewage all over the } \\
\text { lab floor. It is clear that Patroklus has } \\
\text { broken many of the rules of the lab; } \\
\text { his status and honour are clearly } \\
\text { impuned. }\end{array}$ \\
\hline \multicolumn{2}{|c|}{$\begin{array}{r}\text { c.f. lliad 16.828: 'And boasting over him he spoke winged words: 'Patroklus, } \\
\qquad \text { you said, I imagine, that you would sack our city...' }\end{array}$} \\
\hline $\begin{array}{l}\text { Then did you answer him, Patroklus: } \\
\text { 'For now Hektor, boast mightily; } \\
\text { for to you have Zeus, the son of } \\
\text { Cronos, and Apollo granted } \\
\text { victory. But we all must know } \\
\text { that we ourselves will not be } \\
\text { long in life, and even now does } \\
\text { death in the form of } \\
\text { Phenol:Chloroform stand hard } \\
\text { by us all.' }\end{array}$ & $\begin{array}{l}\text { Patroklus argues that sewage on the } \\
\text { floor of the lab is nowhere near as } \\
\text { dangerous as some of the chemicals } \\
\text { that are stored in the lab. } \\
\text { Phenol:Chloroform, mixed 50:50, is } \\
\text { used in molecular biology for purifying } \\
\text { nucleic acids and eliminating } \\
\text { proteins. Chloroform on its own isn't } \\
\text { too harmful; phenol is pretty nasty } \\
\text { stuff. Mixed together they are very } \\
\text { toxic and splashes require immediate } \\
\text { decontamination and, potentially, } \\
\text { hospital treatment. }\end{array}$ \\
\hline $\begin{array}{r}\text { Apostrophization of Patroklus here } \\
\text { trope to indicate that a charc } \\
\text { Italicised section is }\end{array}$ & $\begin{array}{l}\text { reflects the way Homer's lliad uses this } \\
\text { ter is making (or has made) a mistake. } \\
\text { close paraphrasing of lliad 16.844-853 }\end{array}$ \\
\hline
\end{tabular}




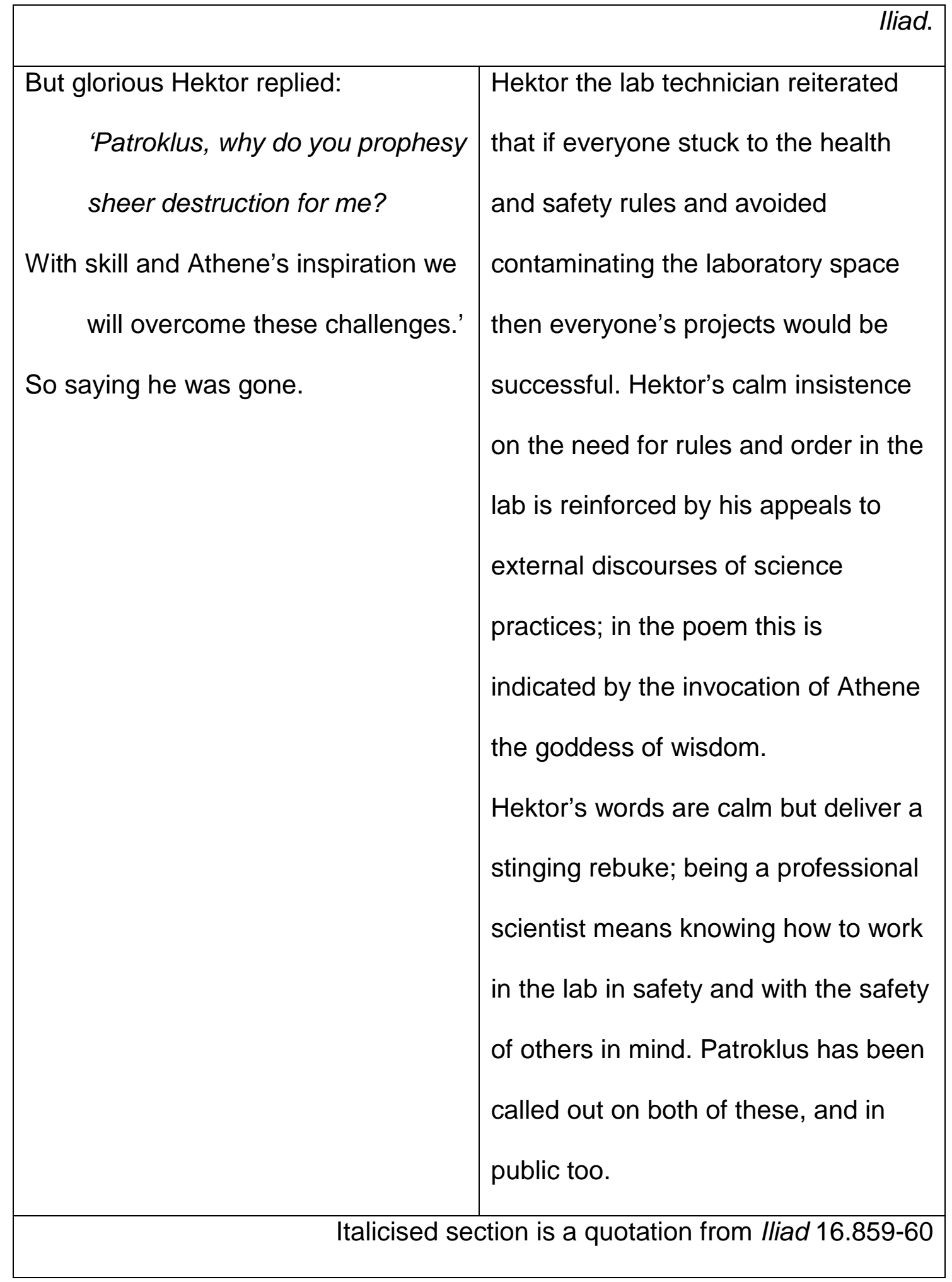

I am not arguing here that the poem is a better (or worse!) description of what is happening in the laboratory. However, I do think that the poem does things which our standard register of social science description and analysis 
struggles with. Firstly, the identification of power is here done through the vehicle of identifying gods and goddesses rather than more conventional agents and objects. This is not to obfuscate; it is, rather, to illustrate the psychosocial attachments that are occurring here. For example, Patroklus has a genuine fear of death in the laboratory, but cannot express this other than in this crisis situation, where emotions are heightened. Conventional accounts of the production of formal scientific knowledge would not see this or would omit

it. Second, the poem juxtaposes the artificial environment of the laboratory and 'nature', but shows the interaction between these two. In earlier parts of the poem we see the laboratory being taken to 'nature' and dominating nature through extraction of samples, measurement of parameters and definition; here we see nature returning to the laboratory and exerting influence inside it. Thirdly, we can identify the unexpected tensions and conflicts inside a research team: Hektor's rebuke is successful because of a status inversion and through the deliberate deployment of the formal discourse of scientific practice and its rules.

\section{Discussion}

Do the verses achieve what they set out to achieve? The idea that someone could write about a modern laboratory as if they were Homer is contentious; I use the phrase 'impossible but not pointless' in describing this project to colleagues. However, the elements of the poem and the reading we can give of them provides a different mode of description, an alternative view that can act as a provocation or irritant to our usual perception of the laboratory setting (or any other site of formal knowledge production). It could 
be argued that this is just a mimetic description; nothing additional is being delivered. This may be the case if we consider just the elements of the poem. However, taken as a whole, the poem does something beyond merely describing the world; it does this in a way that brings in a much wider range of elements - humans, materials, discourses, perceptions, hopes, statuses, relationships - than a 'standard' sociological analysis of the laboratory would. But it also does something different than other 'literary' methods deployed in social studies of science. The New Literary Forms in social studies of science of the 1980s and onwards use innovative styles of writing to address the 'problem' of reflexivity and to make the textual work of representation apparent to the reader (Yearley 2005,101$)$, often using the device of writing in dialogue (Woolgar and Ashmore 1988; Ashmore 1989), or using multiple voices (Mulkay 1991). These studies are attempts to challenge the unitary authorial voice, thus revealing, and revelling in, reflexivity and selfreferentiality. Yet although these textual devices certainly disrupt and confront the reader's relationship to the text, both parties in the dialogue remain embedded within the worldview and conceptual scheme of the present thus reproducing the shared conceptual scheme albeit in different textual styles. The only way we can escape from this, and even then perhaps only partially, is to move into the world of Homer. The Homeric strategy allows us to reimagine the laboratory in a new conceptual context, one that is not arbitrary or fictional; a context that we can have faith in as a basis upon which we can make knowledge claims as to what we are seeing in the site of the production of scientific knowledge. It is, as we would expect from a Feyerabendian methodology, relativist in form, but its content can be realist or constructionist 
descriptions thus promoting methodological pluralism. It cannot achieve its ultimate aim of producing a wholly Homeric account of the lab but it can, through our efforts to achieve this, disrupt our thinking not just about the text, as the New Literary Forms did, but also our thinking about the very concepts we are using in approaching science and science studies. It can also do another important thing; change our relationship to the past. We have an entrenched understanding of the past, particularly the ancient past, as being of use to us only as substrate for historical analysis or moral education. Rather than continuing with this we should follow Steve Fuller's proposal and learn to treat denizens of the past as our contemporaries and, in doing so, perhaps even reconceptualise our own projects (Fuller 2015, 252). From this perspective we can, and indeed must, think about how Homer would make sense of the present we inhabit. Were we to do this we would not only challenge our current conceptual worldview but also open up possibilities for other forms of knowledge long-discarded as 'myth' or even 'madness' to reenter our analyses and converse with on equal terms.

\section{Conclusion}

Our understandings of science and scientific activity are constrained and channelled by our received stories of what it comprises, stories that articulate theories and concepts that are themselves predicated on a long narrative that places theory above experience. These stories are embedded in Western thought in the formal sciences and also in the social sciences and STS. We need to find some way of breaking through our dominating worldview if we are to avoid merely repeating the same stories over and over 
again. As Feyerabend notes: '[t]he transition to the philosophers' "rational" universe ... bore problems that are still waiting to be solved today and that may be altogether unsolvable; a return to some form of myth may be advisable' (Feyerabend 2016, 4). Looking for Homer in the laboratory may be the first step towards this return. If we were to embrace this further, who knows what we might see?

\section{Acknowledgements}

I am indebted to the laboratory workers who participated in this research, gave their time and allowed me to share in their activities.

This paper has been helpfully shaped by discussions with and input from Steve Fuller, Chiara Ambrosia, Catherine Will and Huw Taylor. An earlier version of this paper was presented at the Institute of Microbiology and Infection, University of Birmingham, December 2015.

\section{References}

Adkins, A.W.H. 1970 From the many to the one: a study of personality and views of human nature in the context of ancient Greek society, values and beliefs: London: Constable.

Adkins, A.W.H. 1972 Moral values and political behaviour in Ancient Greece: from Homer to the end of the fifth century, London: Chatto and Windus.

Ashmore, M 1989. The reflexive thesis: wrighting sociology of scientific knowledge. Chicago: University of Chicago Press

Beard, M. 2013. Confronting the Classics: traditions, adventures and innovations, London: Profile. 
Butler, S. 1897. The authoress of the Odyssey, London: Longmans.

Couvalis, G. 1989. Feyerabend's critique of foundationalism. Aldershot: Avebury.

Edwards, M.W. 1991. The Iliad: a commentary. Volume $V$ books 17-20, Cambridge: Cambridge University Press.

Erickson, M. 2015. Science, culture and society: understanding science in the twenty-first century. 2nd edition, Cambridge: Polity.

Feyerabend, P. 1978. Against Method, London: Verso.

Feyerabend, P. 1987. Farewell to Reason, London: Verso.

Feyerabend, P. 1999. Conquest of abundance: a tale of abstraction versus the richness of being. Chicago: University of Chicago Press.

Feyerabend, P. 2011. The tyranny of science, Cambridge: Polity.

Feyerabend, P. [2009] 2016. Philosophy of Nature Cambridge: Polity.

Finley, M.I. 1964. The World of Odysseus, London: Chatto \& Windus.

Fleck, L. 1979. Genesis and Development of a Scientific Fact, Chicago: University of Chicago Press.

Foucault, M. 1970. The Order of Things. An Archaeology of the Human Sciences. London: Tavistock.

Fuller, S. 2010. Science; the art of living, Durham: Acumen.

Fuller, S. 2015. Knowledge: the philosophical quest in history, London: Routledge.

Hainsworth, J.B. 1993. The Iliad: a commentary. Volume III; books 9-12, Cambridge: Cambridge University Press.

Heit, H. 2016. 'Reasons for relativism: Feyerabend on the 'Rise of Rationalism' in ancient Greece', Studies In History and Philosophy of Science Part A. 
Volume 57 pages $70-78$

Hesiod and G.W. Most. 2006. Hesiod, Cambridge, Mass.: Harvard University Press.

Homer and S. Mitchell. 2011. The Iliad, London: Weidenfeld \& Nicolson.

Homer, A.T. Murray, and W. F. Wyatt. 1999. Iliad, Cambridge, Mass.; London: Harvard University Press.

Janko, R. 1992. The Iliad: a commentary. Volume IV books 13-16, Cambridge: Cambridge University Press.

Kirk, G.S. 1985. The Iliad: a commentary. Volume I: books 1 - 4, Cambridge: Cambridge University Press.

Kirk, G.S. 1990. The Iliad: a commentary. Volume II: books 5 - 8. , Cambridge: Cambridge University Press.

Miller, M. 2011. The song of Achilles, London: Bloomsbury.

Mulkay, M. 1991. Sociology of science: a sociological pilgrimage, Milton Keynes: Open University Press.

Nicolson, A. 2014. The mighty dead: why Homer matters. London: William Collins

Popper, K. 1945. The Open Society and Its Enemies, London: Routledge \& Kegan Paul.

Popper, K. [1959] 2002. The logic of scientific discovery, London: Routledge Classics

Popper, K.R. 1998. The world of Parmenides: essays on the Presocratic enlightenment, Abingdon, Oxon ; New York: Routledge.

Preston, J. 1997. Feyerabend: Philosophy, Science and Society, Cambridge: Polity. 
Richardson, N.J. 1993. The Iliad: a commentary. Vol. VI: books 21-24,

Cambridge: Cambridge University Press.

Rorty, R. 1980. Philosophy and the Mirror of Nature, Oxford: Blackwell.

Shapin, S., and S. Schaffe. 1985. Leviathan and the air-pump Princeton, N.J.: Princeton University Press.

Snell, B. 1953. The discovery of the mind in early Greek philosophy and literature: New York: Dover, 1982.

Wallerstein, I.M. 2004. World-systems analysis: an introduction, London: Duke University Press.

Wallerstein, I.M. 2006. European universalism: the rhetoric of power, New York: New Press

Williams, B. 1993. Shame and necessity, Berkeley; Oxford: University of California Press.

Woolgar, S. and M. Ashmore 1988. The next step: an introduction to the reflexive project, In Woolgar, S. (ed) Knowledge and reflexivity: new frontiers in the sociology of knowledge, London: Sage. pp. 1-11.

Yearley, S. 2005. Making sense of science: understanding the social study of science, London: Sage.

\footnotetext{
i An argument could be made to use the works of Hesiod (e.g. Theogony or Work and Days (Hesiod and Most 2006)), but these - whilst remarkable in their own way - do not have the universal stature and acceptance that Homer's works do. And Hesiod's unremitting misogyny is wearing. ii And even this well-known 'fact' is subject to further discussion as the first time the name 'Mentor' is used is when it is the name given to the slain Trojan Imbrius's father in the Iliad ('the spearman Imbrius, the son of Mentor rich in horses' 13.171).
} 
iii The detailed chronology of the Iliad is the subject of much debate. My choice of 54 days is based on the 'symmetrical' interpretation of the chronology of the poem: 27 days up to Book 10 with the night raid, then 27 following days up to the burial of Hektor. Interestingly, one of the most recent translations of the Iliad, Stephen Mitchell's 2011 edition, omits the whole of book 10, which, apart from anything else, rather disrupts the chronology (Homer and Mitchell 2011). 